\title{
Effects of Organizational Values on Quality of Work Life
}

\author{
Maria Isabel de Campos ${ }^{1}$ \\ Universidade São Francisco, Campinas-SP, Brazil
}

\author{
Fabián Javier Marín Rueda \\ Universidade São Francisco, Campinas-SP, Brazil
}

\begin{abstract}
Quality of work life (QWL) is a topic studied globally due to its relevance for workers' health and organizational results. This study investigated the effects of person-organization fit (POF) with regard to workers' perceived and desired organizational values (OV) on QWL. The sample consisted of 213 Brazilians working in companies of different sizes and from different sectors. The quadratic polynomial regression model with surface analysis charts was used. The hypothesis that QWL is affected by satisfaction with OV was confirmed. The surface analysis charts revealed that some of the relationships between variables are non-linear. The conclusion is that these findings can help organizations to reflect on declared values and those actually put into practice in order to develop strategies intended to promote greater congruence from the perspective of employees, positively affecting QWL.
\end{abstract}

Keywords: statistical regression, organizational behavior, working conditions

\section{Efeitos dos Valores Organizacionais Sobre a Qualidade de Vida no Trabalho}

\begin{abstract}
Resumo: A qualidade de vida no trabalho (QVT) é estudada globalmente por sua importância para a saúde do trabalhador e para os resultados organizacionais. Este estudo investiga os efeitos da compatibilidade pessoa organização (POF) no que diz respeito aos valores organizacionais (VO) percebidos e desejados pelos trabalhadores sobre a QVT. Participaram 213 trabalhadores brasileiros de empresas de diferentes portes e setores. Utilizou-se o modelo de regressão polinomial quadrática com análise de gráficos de superfície. Comprovou-se a hipótese de que a QVT é impactada pela satisfação com os VO. A análise de gráficos de superfície permitiu compreender que alguns dos relacionamentos entre as variáveis são curvilíneos. Conclui-se que os achados podem contribuir para que as organizações reflitam sobre seus valores declarados e praticados, desenvolvendo estratégias que possam promover maior congruência na visão de seus funcionários, impactando positivamente na QVT.
\end{abstract}

Palavras-chave: regressão estatística, comportamento organizacional, condições de trabalho

\section{Efectos de los valores organizacionales sobre la calidad de vida laboral}

\begin{abstract}
Resumen: Se estudia la calidad de la vida laboral (CVL) por su importancia para la salud de los trabajadores y para los resultados organizacionales. Fueran investigados los efectos de la compatibilidad persona organización con respecto a los valores organizacionales (VO) percibidos y deseados por los trabajadores en la CVL. La muestra fue de 213 trabajadores brasileños de empresas de diferentes tamaños y sectores. Se utilizó el modelo de regresión polinómica de segundo grado con el análisis de los gráficos de superficie. Se comprobó la hipótesis que CVL se ve afectada por la satisfacción con los VO. Se entendió que algunas de las relaciones entre las variables son curvilíneas. Los hallazgos pueden ayudar a las organizaciones a reflexionar sobre sus valores declarados y practicados, y a desarrollar estrategias para promover una mayor coherencia en la visión de sus empleados, impactando positivamente en CVL.
\end{abstract}

Palabras clave: regresión estadística, conducta organizacional, condiciones de trabajo

This study addresses a recurrent issue in studies conducted in the field of Work and Organizational Psychology (WOP), due to its relevance for the management of human resources within organizations, which is Quality of Work Life (QWL). This subject is addressed from the perspective of the effects on QWL, which is promoted when workers

\footnotetext{
${ }^{1}$ Correspondence address:

Maria Isabel de Campos. Universidade São Francisco, Campus Swift. Rua Waldemar César da Silveira, 105. Jd. Cura D’Ars. CEP 13045-510. Campinas-SP, Brazil. E-mail: isabel@playit.com.br
}

are satisfied with the company's organizational values $(\mathrm{OV})$. This satisfaction depends on the extent to which individuals and organization are compatible (Person-organizational fit $\mathrm{POF}$ ) in terms of OV perceived and desired by workers in the workplace. Tamayo and Borges (2006) define OV as hierarchically organized principles or beliefs concerning desirable organizational behaviors or goals that guide the organization's life and meet individual, collective or mixed interests.

Interest in studying QWL on the part of organizations and researchers started in the 1950s (Walton, 1980). The main motivation of the studies performed since that time is an understanding that improving workers' QWL is a prerequisite to 
improve organizational productivity (Mejbel, Almsafir, Siron, \& Alnaser, 2013).

This view is easily verified in Walton (1973), for whom QWL can be defined as a set of initiatives, the objective of which is to improve human experience in the workplace while increasing the organization's competitiveness by redesigning its nature, obtaining productivity gains. The theoretical model established by this author presents QWL as a multidimensional concept that comprises fair and appropriate compensation, working conditions, the opportunity to use and develop workers' capabilities, the opportunity for continuous growth and safety, social integration at work, constitutionalism, work itself and life as a whole, and the relevance of life at work. According to Pedroso and Pilatti (2010), among the many theoretical models developed for QWL, the model by Walton (1973) remains one of the most frequently used to support research in the field. Being considered the most comprehensive, it is the most used model in Brazil.

Studies involving QWL measures have been conducted in Brazil in an attempt to understand how its nomological network is formed and how to use measures, and the insights these promote, in organizational environments (Mendonça, Hora, Costa, \& Monteiro, 2014; Nespeca \& Cyrillo, 2011; Silva \& Ferreira, 2013). Studies seeking to develop and improve measuring instruments include Rueda, Ottati, Pinto, Lima and Bueno (2013). The authors report on the development of a scale to assess QWL, the Escala-QVT [QWL-Scale] and the initial findings regarding its validity.

The QWL-Scale has been used in various studies, including the research by Rueda, Serenini and Meireles (2014), which assessed the relationships between QWL and trust in the organization, showing a strong association between these constructs. This instrument was also used in the study conducted by Campos and Rueda (2016) to investigate the relationship between moral harassment at work and QWL. The conclusion was that the relationship between both is of low magnitude but presents an effect suggesting that interventions intended to decrease moral harassment at work can also improve the QWL among employees.

QWL has been studied worldwide and research has been conducted in Saudi Arabia, where the relationship between QWL and turnover intention was addressed in health services (Almalki, FitzGerald, \& Clark, 2012); in Iran, where the relationship among leadership behavior, QWL and productivity was verified (Barzegar, Afzal, Tabibi, Delgoshaei, \& Koochakyazdi, 2012); in Turkey, where QWL was analyzed as a predictor of alienation at work among the teachers of a primary school (Erdem, 2014); and in Nigeria, where organizational climate, leadership style and emotional intelligence were investigated as predictors of QWL (Adeyemo, Terry, \& Lambert, 2015).

Among the various studies conducted in Europe, there is the survey conducted by Šverko and Galić (2014). It addressed QWL as perceived by 36,472 workers from Croatia, from 17 countries in Western Europe (EU17) and another ten countries from Central and Eastern Europe (EU10), which were previously socialist countries. The findings indicate that QWL in the EU17 is considered superior to that observed in the other two groups with regard to economic security, meaning of work, autonomy and participation in decision-making.

Studies were also conducted in Canada (Nowrouzi et al., 2015), Mexico (Argüelles Ma, Quijano García, Fajardo, Magaña Medina, \& Sahuí Maldonado, 2014), Australia (Ouppara \& Sy, 2012) and Colombia (Contreras, Espinosa, Hernández, \& Acosta, 2013). All these papers published globally reinforce the understanding that QWL remains a topic of great interest both in academia and organizations and space remains to contribute to a better understanding.

No studies were found in Brazil linking QWL and OV (within the POF context) after a search was conducted including papers published up to February 2016, using the equivalent of "organizational values" and "quality of life at work" in Portuguese in the IndexPsi database and Google Scholar. The studies found, however, addressed the effects of POF in the context of OV on other work-related constructs. Sousa and Porto (2015) investigated the impact of this congruence on happiness at work, concluding that OV congruence affects happiness at work.

Oliveira and Souza (2014), in turn, verified the predictive power of personal values (PV) and organizational values regarding workers' trust in the organization. PV explained a smaller percentage of variance when compared to $\mathrm{OV}$, indicating that workers' trust in the organization seems to be based on an evaluation of the organizational system. According to the authors, OV could be perceived as more relevant than PV when explaining trust in the organization, which according to Rueda et al. (2014) is strongly associated with QWL.

In order to build on previous studies, this study's objective was to verify the effects of OV on QWL. More specifically, effects will be investigated through the satisfaction of workers with OV. This satisfaction is usually assessed through real OV and desired OV (Tamayo \& Borges, 2006; Tamayo, Mendes, \& Paz, 2000). The hypothesis is that the existence of POF, that is, compatibility between individual and organization with regard to perceived and desired $\mathrm{OV}$, positively affects QWL.

\section{Method}

\section{Participants}

A total of 213 people who belonged to the authors' contact network, residing in various Brazilian states, were recruited through email, Facebook and LinkedIn; 174 (81.7\%) of which were from the state of São Paulo. People were aged 33.40 years old $(S D=10.99)$ on average and $115(54 \%)$ were men. In terms of education, $203(95.3 \%)$ reported holding an undergraduate, college or graduate degree.

With regard to the organizations where the participants worked, 57 people $(26.8 \%)$ reported companies with up to 30 employees, 88 (41.3\%) worked in companies from 31 to 100 employees, $44(20.7 \%)$ reported companies from 101 to 300 employees, 3 (1.4\%) reported from 301 to 500 employees, and $21(9.9 \%)$ worked in companies with more than 500 employees. Eighteen (8.5\%) participants reported they occupied executive positions, being vice-president or president, 
$31(14.6 \%)$ were managers, $38(17.8 \%)$ were supervisors or coordinators, and $126(59.2 \%)$ reported other functions within the company; time working in the company ranged from 0 to 31 years; 3.49 years $(S D=5.08)$ on average.

\section{Instruments}

Inventário de Valores Organizacionais - IVO [Organizational Values Inventory - OVI] (Tamayo et al., 2000). This instrument is composed of six bipolar factors. Polarities are distributed along three axes arranged as follows: autonomy (4 items, $\alpha=0.83$ ) versus conservatism (5 items, $\alpha=0.77$ ); hierarchy (10 items, $\alpha=0.87$ ) versus egalitarianism ( 7 items, $\alpha=0.85$ ); and mastery (8 items, $\alpha=0.84$ ) versus harmony ( 2 items, $\alpha=0.85$ ).

The OVI measures real values, those employees perceive that are practiced by the organization, and desired values, that is, those values that employees believe should be practiced by the organization. Score is achieved through a Likert-style scale ranging from $0=$ not important at all to $6=$ very important, while 36 items are answered twice according to "how important each item is in the current context of your organization" (real value - RV) and "how important each item should be in your organization" (desired value - DV).

Therefore, for both real and desired values, the autonomy factor measures the organization's willingness to perceive employees as autonomous individuals, capable to follow their own interests and establish personal goals that are compatible with the organization's goals and standards. At the opposite end, the conservatism factor represents the preservation of customs and traditions and power structures, keeping the status quo and restricting behaviors that disturb the company's norms and traditions.

The hierarchy factor assesses the extent to which the company values authority, social power, influence, surveillance and supervision, as opposed to egalitarianism, which assesses the extent to which the company values the well being of people and of the organization in general, the existence of few hierarchical levels, participatory management, justice and equality. Finally, in the third axis, the mastery factor assesses the company's assertiveness through the mastery of material resources, of the market, technology and knowledge in its field while, at the opposite end, the harmony factor assesses how harmoniously the company positions itself in its environment, respecting nature and competitors.

Escala de Qualidade de Vida no Trabalho - Escala-QVT [Quality of Work Life - QWL-Scale] - (Rueda, 2013). It is composed of 35 items, divided into four factors measured on a Likert scale ranging from $1=$ strongly disagree to $5=$ strongly agree.

Factor 1, QWL related to integration, respect and autonomy (IRA, $\alpha=0.90$ ), is composed of 15 items. It refers to the promotion of respect for individual differences and for the employees' rights, collaboration and respect among coworkers, and the promotion of autonomy through clear rules and standards; Factor 2, QWL related to fair and appropriate compensation (FAC, $\alpha=0.89$ ), is composed of six items. It refers to QWL linked to one's satisfaction with salary and the com- pany's wage policies, perceiving it to be fair; factor 3, QWL related to incentive and support (IS, $\alpha=0.82$ ) is composed of eight items. It refers to incentives and support provided in terms of training programs, improving courses, and incentive to perform cultural activities; factor 4 , QWL related to the possibility of leisure and social interaction (PLSI, $\alpha=0.84$ ) is composed of six items and refers to the quality of social life outside the organization that is promoted on the basis of the own organization's characteristics, such as working hours, working days and workload. Total scores result from adding up the scores assigned to each of the factor's items, which can range from 0 to 75 for factor 1 , from 0 to 30 for factors 2 and 4 , and from 0 to 40 for factor 3 .

\section{Procedure}

Data collection. Data were collected through a proprietary tool available on the Internet. This tool is based on Java language and used PostgreeSQL, a free database management system. A server with secure access and database in an isolated system was used.

In its first screen, the tool presented the free and informed consent form. After respondents had consented and confirmed they were aware they were free to withdraw from the survey at any time, the questionnaires were presented. OVI was first presented, followed by the QWL-Scale. Response time was approximately 25 minutes.

Data analysis. Data were analyzed using SPSS, version 20. The precision indexes of the scales' factors were verified using Cronbach's alpha.

Finally, quadratic regression was performed as recommended by Edwards and Parry (1993) and later detailed by Shanock, Baran, Gentry, Pattison and Heggestad (2010). Quality of Work Life was the dependent variable and real and desired values were the independent variables. A total of 24 regressions were performed using the formula: $\mathrm{Z}=\mathrm{b}_{0}+\mathrm{b}_{1} \mathrm{X}+\mathrm{b}_{2} \mathrm{Y}+\mathrm{b}_{3} \mathrm{X}^{2}+\mathrm{b}_{4} \mathrm{XY}+\mathrm{b}_{5} \mathrm{Y}^{2}$ $+\mathrm{e}$, where $\mathrm{Z}$ represents the scores for each of the factors in the QWL-Scale, X represents the scores of each of the OVI factors in its component of real values, Y represents the scores of each of the OVI factors in its component of desired values, $b_{0}$ to $b_{5}$ represent the equation's constants, and " $\mathrm{e}$ " represents error.

With the results, we also calculated the coefficient values $a_{1}$ and $a_{2}$, which determine the slope and curvature of the line of total congruence $(\mathrm{RV}=\mathrm{DV})$; and $\mathrm{a}_{3}$ and $\mathrm{a}_{4}$, which determine the slope and curvature of the line of total incongruence (RV = -DV). These are the coefficients that permit the analysis of the surface test and its interpretation (Edwards \& Parry, 1993; Shanock et al., 2010). This method was chosen because, since the 1990's, researchers have discovered that the use of quadratic regression can considerably increase the explained variance in POF studies (Saraç, Efil, \& Eryilmaz, 2014).

\section{Ethical Considerations}

This study was submitted to and approved by the Institutional Review Board at Universidade São Francisco (CAAE 15120713.2.0000.5514). 


\section{Results}

The following precision indexes were obtained for the OVI (in the parentheses appear real values first and then desired values): autonomy $(0.85 ; 0.67)$, conservatism $(0.76 ; 0.66)$, hierarchy $(0.88 ; 0.91)$, egalitarianism $(0.88 ; 0.80)$, mastery $(0.82 ; 0.75)$, and harmony $(0.51 ; 0.77)$. The following were found for the QWL-Scale: 0.90 (IRA), 0.94 (FAC), 0.78 (IS) and 0.88 (PLSI). The $\alpha=0.51$ found for the OVI's harmony factor is considered unacceptable (Maroco \& Garcia-Marques, 2006). Note that this factor is composed of two items only, which together with the sample size may have led to this result. Even though no satisfactory conclusions can be achieved with regard to this factor, its results are also presented in the tables.

The calculation of the means for the OVI factors, in turn, indicated that all the means concerning desired values were greater than the means concerning real values with statistical significance at $p<0.001$, obtained by Student's $t$-test. Quadratic regressions were performed to assess the impact of satisfaction with OV on QWL, considering a combination of real and desired values. The results are presented in Tables 1, 2 and 3.

Table 1

Effects of Organizational Values on Quality of Work Life

\begin{tabular}{|c|c|c|c|c|c|c|c|}
\hline \multirow[b]{2}{*}{ QWL-Scale } & \multirow[b]{2}{*}{ OVI } & \multicolumn{6}{|c|}{ Quadratic regression (real and desired values*) } \\
\hline & & $R$ & $R 2$ & $R 2$ adjusted & $S D$ & $F$ & $P$ \\
\hline \multirow{6}{*}{$\begin{array}{l}\text { Integration, respect and autonomy } \\
\text { (IRA) }\end{array}$} & Autonomy & 0.57 & 0.33 & 0.31 & 8.22 & 20.19 & 0.000 \\
\hline & Conservatism & 0.55 & 0.30 & 0.29 & 8.37 & 18.06 & 0.000 \\
\hline & Hierarchy & 0.45 & 0.20 & 0.18 & 8.96 & 10.48 & 0.000 \\
\hline & Egalitarianism & 0.58 & 0.34 & 0.32 & 8.17 & 20.99 & 0.000 \\
\hline & Mastery & 0.47 & 0.22 & 0.20 & 8.86 & 11.60 & 0.000 \\
\hline & Harmony & 0.41 & 0.17 & 0.15 & 9.16 & 8.21 & 0.000 \\
\hline \multirow{6}{*}{$\begin{array}{l}\text { Fair and appropriate compensation } \\
\qquad(\text { FAC) }\end{array}$} & Autonomy & 0.48 & 0.23 & 0.21 & 6.02 & 12.15 & 0.000 \\
\hline & Conservatism & 0.36 & 0.13 & 0.11 & 6.39 & 6.15 & 0.000 \\
\hline & Hierarchy & 0.32 & 0.10 & 0.08 & 6.48 & 4.76 & 0.000 \\
\hline & Egalitarianism & 0.49 & 0.24 & 0.22 & 5.98 & 12.82 & 0.000 \\
\hline & Mastery & 0.37 & 0.14 & 0.12 & 6.35 & 6.64 & 0.000 \\
\hline & Harmony & 0.35 & 0.12 & 0.10 & 6.42 & 5.59 & 0.000 \\
\hline \multirow{6}{*}{$\begin{array}{l}\text { Incentive and support } \\
\text { (IS) }\end{array}$} & Autonomy & 0.58 & 0.34 & 0.32 & 5.79 & 21.17 & 0.000 \\
\hline & Conservatism & 0.51 & 0.26 & 0.24 & 6.14 & 14.18 & 0.000 \\
\hline & Hierarchy & 0.49 & 0.24 & 0.23 & 6.19 & 13.28 & 0.000 \\
\hline & Egalitarianism & 0.67 & 0.44 & 0.43 & 5.31 & 32.97 & 0.000 \\
\hline & Mastery & 0.50 & 0.25 & 0.23 & 6.17 & 13.68 & 0.000 \\
\hline & Harmony & 0.48 & 0.23 & 0.21 & 6.25 & 12.24 & 0.000 \\
\hline \multirow{6}{*}{$\begin{array}{l}\text { Possibilities of leisure and social } \\
\text { interaction }\end{array}$} & Autonomy & 0.41 & 0.17 & 0.15 & 5.15 & 8.42 & 0.000 \\
\hline & Conservatism & 0.32 & 0.10 & 0.08 & 5.37 & 4.55 & 0.001 \\
\hline & Hierarchy & 0.31 & 0.09 & 0.07 & 5.38 & 4.27 & 0.001 \\
\hline & Egalitarianism & 0.46 & 0.21 & 0.19 & 5.02 & 11.21 & 0.000 \\
\hline & Mastery & 0.30 & 0.09 & 0.07 & 5.39 & 4.16 & 0.001 \\
\hline & Harmony & 0.30 & 0.09 & 0.07 & 5.40 & 4.00 & 0.002 \\
\hline
\end{tabular}

*Note: According to the regression equation $\mathrm{Z}=\mathrm{b}_{0}+\mathrm{b}_{1} \mathrm{X}+\mathrm{b}_{2} \mathrm{Y}+\mathrm{b}_{3} \mathrm{X}^{2}+\mathrm{b}_{4} \mathrm{XY}+\mathrm{b}_{5} \mathrm{Y}^{2}+\mathrm{e}$, where $\mathrm{Z}$ represents the scores of each of the factors in the QLW-Scale, X represents the scores of each of the OVI factors in its component of real values, Y represents the scores of the OVI factors in its component of desired factors, $b_{0}$ till $b_{5}$ represent the constants of the equation and "e" represents error.

As shown in Table 1, all the regressions present statistical significance, four of which refer to the factor possibility of leisure and social interaction of the QWL-Scale at $p<0.005$ and the remaining at $p<0.001$. The OVI's egalitarianism factor explained most variance with regard to all QWL factors, presenting $\Delta R^{2}=0.43$ of the effect on the IS factor. Factor PLSI, in turn, indicated the smallest impact regarding OV.
Yet, the OVI's egalitarianism factor presented $\Delta R^{2}=0.19$ for this aspect of QWL.

In the quadratic regression, the coefficients $b_{1}$ to $b_{5}$ and their respective standard deviations made it possible to obtain the slope and curvature of surfaces along the lines of congruence and discrepancy (perfect incongruity). These results, as well as those related to the intercept $\left(b_{0}\right)$, are presented in 
Information provided in Table 2 shows that all the values found for the intercepts of the equations presented statistical significance; the same is true only for some of the coefficients $\mathrm{b}_{1}$ to $\mathrm{b}_{5}$. The slope and curvature coefficients of the lines of congruency and discrepancy are presented in Table 3, toge- ther with the covariance among the equation coefficients. Covariances are important in this type of analysis because, like coefficients $b_{1}$ to $b_{5}$ and their respective standard deviations, covariances are used to verify the statistical significance of coefficients $\mathrm{a}_{1}$ to $\mathrm{a}_{4}$ (Shanock et al., 2010).

Table 2

Coefficients and Standard Deviations in the Quadratic Polynomial Equation (Regression)

\begin{tabular}{|c|c|c|c|c|c|c|c|c|c|c|c|c|c|}
\hline & & Intercep & & $X(\operatorname{Re}$ & & Y (Des) & ed) & $\mathrm{X}^{2}$ & & $\mathrm{XY}$ & & $\mathrm{Y}^{2}$ & \\
\hline QWL-Scale & OVI & $\mathrm{b}_{0}$ & $S D$ & $\mathrm{~b}_{1}$ & $S D$ & $\mathrm{~b}_{2}$ & $S D$ & $\mathrm{~b}_{3}$ & $S D$ & $\mathrm{~b}_{4}$ & $S D$ & $\mathrm{~b}_{5}$ & $S D$ \\
\hline \multirow{6}{*}{ IRA } & F1 & $69.56^{*}$ & 5.65 & 2.28 & 2.77 & -8.59 & 5.69 & -0.71 & 0.40 & 1.32 & 1.17 & 1.53 & 1.37 \\
\hline & F2 & $69.90^{*}$ & 6.21 & 3.52 & 3.16 & -11.09 & 6.24 & -0.71 & 0.46 & 1.11 & 1.33 & 2.14 & 1.53 \\
\hline & F3 & $59.85^{*}$ & 1.47 & -2.77 & 2.19 & 0.31 & 2.03 & $0.47^{\mathrm{a}}$ & 0.56 & 2.70 & 0.95 & -0.76 & 0.72 \\
\hline & $\mathrm{F} 4$ & $66.81^{*}$ & 3.06 & $4.11^{\mathrm{a}}$ & 1.91 & $-6.99^{a}$ & 3.45 & -0.19 & 0.42 & 0.47 & 0.80 & 1.52 & 0.94 \\
\hline & F5 & $63.97^{*}$ & 2.30 & -0.48 & 2.29 & -3.43 & 3.12 & $-2.52^{*}$ & 0.69 & $3.55^{\mathrm{a}}$ & 1.18 & 0.36 & 0.99 \\
\hline & F6 & $61.52^{*}$ & 1.33 & 0.10 & 1.23 & 0.50 & 1.35 & -0.60 & 0.33 & $1.57^{\mathrm{a}}$ & 0.58 & -0.53 & 0.45 \\
\hline \multirow{6}{*}{ FAC } & $\mathrm{F} 1$ & $13.00^{\mathrm{a}}$ & 4.13 & 3.71 & 2.03 & 5.08 & 4.16 & -0.19 & 0.29 & -0.41 & 0.86 & -1.35 & 1.01 \\
\hline & $\mathrm{F} 2$ & $10.29^{\mathrm{b}}$ & 4.74 & -1.73 & 2.41 & 6.86 & 4.76 & $-0.73^{b}$ & 0.35 & 1.88 & 1.02 & -1.64 & 1.17 \\
\hline & F3 & $17.35^{*}$ & 1.06 & -0.21 & 1.59 & 0.06 & 1.47 & 0.31 & 0.40 & 0.81 & 0.69 & -0.24 & 0.52 \\
\hline & $\mathrm{F} 4$ & $18.92^{*}$ & 2.24 & $3.07^{\mathrm{a}}$ & 1.40 & -1.40 & 2.53 & 0.24 & 0.30 & -0.13 & 0.59 & 0.25 & 0.69 \\
\hline & F5 & $15.19^{*}$ & 1.65 & 2.25 & 1.64 & 2.77 & 2.24 & -0.20 & 0.49 & 0.12 & 0.85 & -0.85 & 0.71 \\
\hline & F6 & $18.71^{*}$ & 0.93 & $2.50^{\mathrm{a}}$ & 0.87 & 0.29 & 0.95 & -0.04 & 0.24 & -0.40 & 0.41 & -0.29 & 0.32 \\
\hline \multirow{6}{*}{ IS } & $\mathrm{F} 1$ & $24.83^{*}$ & 3.97 & $5.08^{b}$ & 1.95 & -3.06 & 4.00 & -0.17 & 0.28 & -0.61 & 0.83 & 0.61 & 0.97 \\
\hline & F2 & $15.64^{\mathrm{a}}$ & 4.56 & 1.87 & 2.32 & 3.90 & 4.58 & -0.63 & 0.34 & 0.86 & 0.98 & -0.75 & 1.13 \\
\hline & F3 & $21.34^{*}$ & 1.01 & 0.71 & 1.52 & 0.80 & 1.40 & -0.08 & 0.38 & 1.23 & 0.66 & -0.59 & 0.50 \\
\hline & $\mathrm{F} 4$ & $29.07^{*}$ & 1.99 & $5.06^{*}$ & 1.24 & $-7.90^{\mathrm{a}}$ & 2.24 & -0.40 & 0.27 & -0.36 & 0.52 & $2.04^{\mathrm{a}}$ & 0.61 \\
\hline & F5 & $19.19^{*}$ & 1.60 & 1.10 & 1.59 & 3.38 & 2.17 & -0.12 & 0.48 & 1.21 & 0.82 & -1.25 & 0.69 \\
\hline & F6 & $23.24^{*}$ & 0.91 & $2.17^{\mathrm{b}}$ & 0.84 & 0.66 & 0.92 & 0.02 & 0.23 & 0.21 & 0.40 & -0.57 & 0.31 \\
\hline \multirow{6}{*}{ PLSI } & $\mathrm{F} 1$ & $23.57^{*}$ & 3.54 & -0.31 & 1.74 & -1.57 & 3.57 & -0.14 & 0.25 & 0.95 & 0.74 & 0.30 & 0.86 \\
\hline & $\mathrm{F} 2$ & $20.72^{*}$ & 3.99 & 1.07 & 2.03 & 0.14 & 4.00 & -0.44 & 0.30 & 0.40 & 0.85 & 0.12 & 0.98 \\
\hline & F3 & $20.73^{*}$ & 0.88 & -1.09 & 1.32 & 1.22 & 1.22 & -0.05 & 0.33 & 1.01 & 0.57 & -0.27 & 0.43 \\
\hline & F4 & $22.69^{*}$ & 1.88 & 1.63 & 1.18 & -0.79 & 2.12 & 0.11 & 0.26 & 0.23 & 0.49 & 0.21 & 0.58 \\
\hline & F5 & $22.07^{*}$ & 1.40 & 0.18 & 1.39 & -0.82 & 1.90 & -0.55 & 0.42 & 0.81 & 0.72 & 0.40 & 0.60 \\
\hline & F6 & $21.21^{*}$ & 0.78 & -0.71 & 0.73 & $1.83^{\mathrm{b}}$ & 0.80 & -0.38 & 0.20 & $0.78^{\mathrm{b}}$ & 0.34 & -0.37 & 0.27 \\
\hline
\end{tabular}

Note. IRA = Integration, respect and autonomy; FAC = Fair and appropriate compensation; IS = Incentive and support; PLSI = Possibilities of leisure and social interaction; F1 = Autonomy; F2 = Conservatism; F3 = Hierarchy; F4 = Egalitarianism; F5 = Mastery; F6 = Harmony. ${ }^{*} p<0.001 ;{ }^{\mathrm{a}} p<0.01 ;{ }^{\mathrm{b}} p<0.05$ 
Table 3

Covariances Between Regression Coefficients and Coefficients of Slope and Curvature of Surface Analysis Charts

\begin{tabular}{|c|c|c|c|c|c|c|c|c|c|}
\hline \multirow[b]{2}{*}{ QWL-Scale } & \multirow[b]{2}{*}{ OVI } & \multicolumn{4}{|c|}{ Covariance } & \multicolumn{4}{|c|}{ Slope and curvature } \\
\hline & & $\mathrm{b}_{1} \mathrm{~b}_{2}$ & $\mathrm{~b}_{3} \mathrm{~b}_{4}$ & $\mathrm{~b}_{3} \mathrm{~b}_{5}$ & $\mathrm{~b}_{4} \mathrm{~b}_{5}$ & $a_{1}$ & $\mathrm{a}_{2}$ & $\mathrm{a}_{3}$ & $\mathrm{a}_{4}$ \\
\hline \multirow{6}{*}{ IRA } & $\mathrm{F} 1$ & -9.76 & -0.24 & 0.08 & -0.95 & -6.30 & 2.14 & 10.87 & -0.50 \\
\hline & $\mathrm{F} 2$ & -4.85 & -0.23 & 0.03 & -0.72 & -7.57 & 2.54 & 14.61 & 0.32 \\
\hline & F3 & -2.80 & -0.15 & -0.06 & -0.40 & -2.47 & $2.41^{\mathrm{a}}$ & -3.08 & -2.98 \\
\hline & F4 & -4.11 & -0.13 & -0.07 & -0.38 & -2.89 & $1.80^{\mathrm{b}}$ & $11.10^{\mathrm{b}}$ & 0.86 \\
\hline & F5 & -4.81 & -0.44 & 0.05 & -0.73 & -3.90 & 1.28 & 2.95 & -5.82 \\
\hline & F6 & -0.99 & -0.09 & 0.01 & -0.14 & 0.59 & 0.44 & -0.40 & -2.69 \\
\hline \multirow{6}{*}{ FAC } & $\mathrm{F} 1$ & -5.23 & -0.13 & 0.04 & -0.51 & $8.80^{\mathrm{a}}$ & $-1.95^{b}$ & -1.37 & -1.12 \\
\hline & $\mathrm{F} 2$ & -2.82 & -0.13 & 0.02 & -0.42 & 5.14 & -0.48 & -8.59 & $-4.25^{b}$ \\
\hline & F3 & -1.47 & -0.08 & -0.03 & -0.21 & -0.16 & 0.88 & -0.27 & -0.74 \\
\hline & $\mathrm{F} 4$ & -2.20 & -0.07 & -0.04 & -0.20 & 1.68 & 0.37 & 4.47 & 0.63 \\
\hline & F5 & -2.47 & -0.23 & 0.02 & -0.38 & $5.01^{\mathrm{a}}$ & -0.93 & -0.52 & -1.16 \\
\hline & F6 & -0.49 & -0.04 & 0.01 & -0.07 & $2.79^{\mathrm{a}}$ & $-0.72^{b}$ & 2.21 & 0.07 \\
\hline \multirow{6}{*}{ IS } & $\mathrm{F} 1$ & -4.84 & -0.12 & 0.04 & -0.47 & 2.02 & -0.17 & 8.14 & 1.06 \\
\hline & F2 & -2.61 & -0.12 & 0.02 & -0.39 & 5.77 & -0.52 & -2.03 & -2.24 \\
\hline & F3 & -1.34 & -0.07 & -0.03 & -0.19 & 1.52 & 0.55 & -0.09 & $-1.90^{\mathrm{b}}$ \\
\hline & $\mathrm{F} 4$ & -1.74 & -0.05 & -0.03 & -0.16 & -2.84 & $1.28^{\mathrm{a}}$ & $12.96^{\mathrm{a}}$ & 2.00 \\
\hline & F5 & -2.33 & -0.22 & 0.02 & -0.36 & $4.47^{\mathrm{a}}$ & -0.16 & -2.28 & -2.57 \\
\hline & F6 & -0.46 & -0.04 & 0.01 & -0.06 & $2.83^{\mathrm{a}}$ & -0.35 & 1.51 & -0.76 \\
\hline \multirow{6}{*}{ PLSI } & F1 & -3.84 & -0.10 & 0.03 & -0.37 & -1.88 & 1.10 & 1.26 & -0.79 \\
\hline & $\mathrm{F} 2$ & -1.99 & -0.10 & 0.01 & -0.29 & 1.20 & 0.09 & 0.93 & -0.72 \\
\hline & F3 & -1.01 & -0.06 & -0.02 & -0.15 & 0.13 & 0.68 & -2.32 & -1.33 \\
\hline & F4 & -1.55 & -0.05 & -0.03 & -0.14 & 0.84 & 0.54 & 2.41 & 0.08 \\
\hline & F5 & -1.78 & -0.16 & 0.02 & -0.27 & -0.64 & 0.66 & 1.00 & -0.95 \\
\hline & F6 & -0.34 & -0.03 & 0.01 & -0.05 & 1.12 & 0.03 & -2.53 & $-1.52^{b}$ \\
\hline
\end{tabular}

Note. IRA = Integration, respect and autonomy; FAC $=$ Fair and appropriate compensation; IS $=$ Incentive and support; PLSI $=$ Possibilities of leisure and social interaction; F1 = Autonomy; F2 = Conservatism; F3 = Hierarchy; F4 = Egalitarianism; F5 = Mastery; F6 = Harmony.

${ }^{\mathrm{a}} p<0.01,{ }^{\mathrm{b}} p<0.05$.

It can be noted in Table 3 that, only for PLSI, as a dependent variable, the slope and curvature coefficients did not present any information with statistical significance, since the only exception in this case was the harmony factor, as an independent variable. Given the Cronbach's alpha found for the $\mathrm{RV}$ calculation of this factor, the result found cannot be safely interpreted. Additionally, the statistically significant results for $\mathrm{a}_{2}$ and $\mathrm{a}_{4}$ indicate the existence of non-linear relationships between: OVI's hierarchic and egalitarianism factors with QWL's IRA; OVI's autonomy and conservatism factors with QWL's FAC; OVI's hierarchy and egalitarianism factors with QWL's IS.

The results presented so far made it possible to plot surface analysis charts. To understand these analyses, two of the six charts that present non-linear relationships are presented here. They were chosen considering the level of statistical 
significance obtained for the coefficients and number of coefficients with statistical significance. Hence, Figure 1 presents the surface analysis chart of the effect of satisfaction with the egalitarianism value in the QWL related to incentive and support. Figure 2 presents the effect of satisfaction with the autonomy value in QWL related to fair and appropriate compensation. All the charts are available to whoever may be interested by contacting the corresponding author.

The two figures show the term 'centralized' beside axes $\mathrm{X}$ and $\mathrm{Y}$. It indicates that the predictor variables real values and desired values had their values centralized, as recommended in the literature, to perform the quadratic regression analysis intended to aid in the interpretation and to reduce potential for multicollinearity (Shanock et al., 2010).

Information provided in Table 3 and the chart in Figure 1 suggest that the slope in the surface along the line of congruence $(\mathrm{RV}=\mathrm{DV})$ is negative and the surface curvature is concave $\left(\mathrm{a}_{1}=-2.84\right.$, not significant; $\left.\mathrm{a}_{2}=1.28, p<0.05\right)$. Therefore, QWL related to IS, along the line of congruence, increases more sharply when perceived egalitarianism (RV) and desired egalitarianism (DV) obtain low scores, and less sharply in the contrary direction, in which congruence obtains high scores. Some examples of these scores in this line that help to understand the curve are: for $\mathrm{RV}=\mathrm{DV}=-3$, IS $=49.10$; for $\mathrm{RV}=\mathrm{DV}=0, \mathrm{IS}=29.07$; for $\mathrm{RV}=\mathrm{DV}=3$, IS $=32.08$.

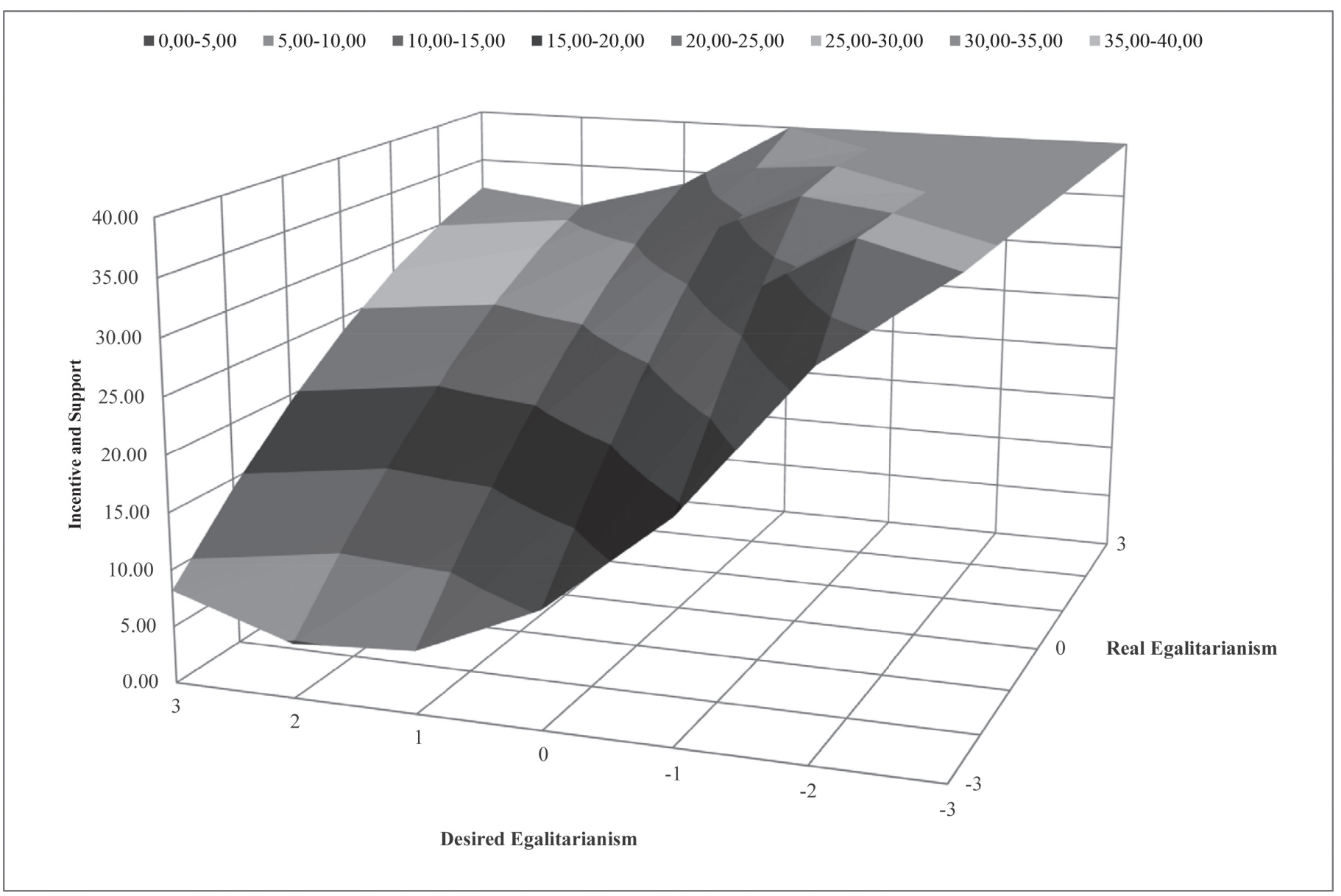

Figure 1. Effect of Satisfaction With the Egalitarianism Value on QWL Related to Incentive and Support.

In turn, the slope of the surface along the line of perfect incongruence $(\mathrm{RV}=-\mathrm{DV})$ is positive and the surface is linear $\left(\mathrm{a}_{3}=12.96, p<0.001 ; \mathrm{a}_{4}=2.00\right.$, not significant $)$. Therefore, QWL related to IS is lower when scores concerning perceived and desired egalitarianism (RV and DV) are lower, and increases when, along this line, RV and DV scores are higher. Some examples of these scores in this line that help to understand the curve are: for $(\mathrm{RV}, \mathrm{DV})=(3,-3)$, IS $=85.94$; for $(\mathrm{RV}, \mathrm{DV})=(0,0), \mathrm{IS}=29.07$; for $(\mathrm{RV}, \mathrm{DV})=(-3,3)$, IS = 8.16. Finally, the chart also shows that, in other situations of incongruence, the QWL related to IS is greater when real ega- litarianism is greater than the desired (RV $>\mathrm{DV})$ and is lower when the opposite occurs, that is, when desired egalitarianism is greater than the real (DV > RV).

Concerning the effect of satisfaction with autonomy on QWL related to FAC, the chart in Figure 2 and information provided in Table 3 indicate that the slope of the surface along the line of congruence is positive and the surface is convex $\left(\mathrm{a}_{1}\right.$ $=8.80, p<0.05 ; \mathrm{a}_{2}=-1.95, p<0.05$ ). For the surface along the line of perfect incongruence, data were not significant (n.s.) $\left(\mathrm{a}_{3}=-1.37\right.$, n.s.; $\mathrm{a}_{4}=-1.12$, n.s. $)$ and, even though the chart shows the negative slope and the convex curve, these data are 
not interpreted safely. These results allow us understand that QWL related to FAC increases along the line of congruence to the extent in which scores of real and desired autonomy increase. On the opposite, the QWL related to FAC decreases more sharply than in relation to the increase, when the real and desired autonomy scores decrease.

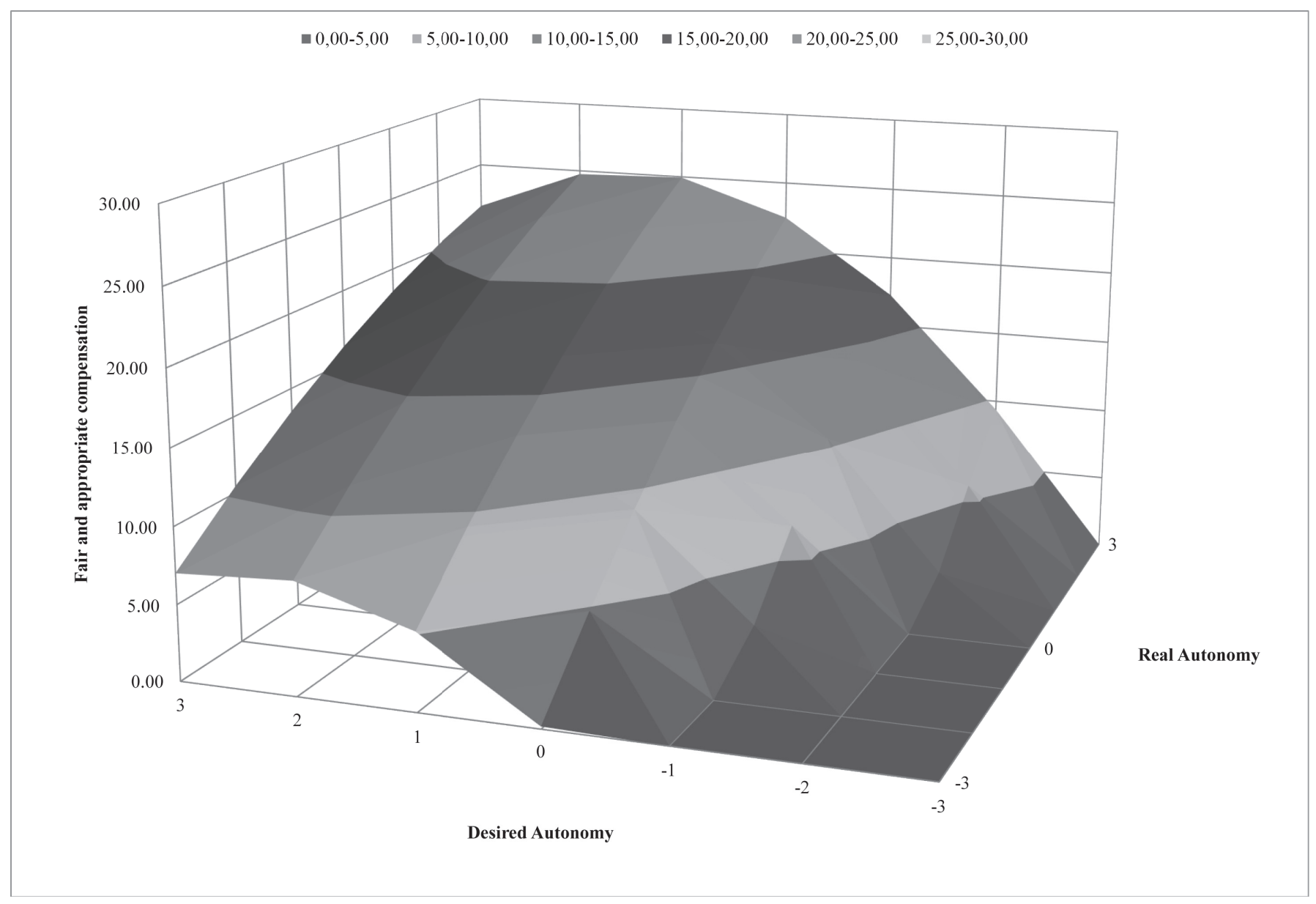

Figure 2. Effect of Satisfaction With Autonomy Value on QWL Related to Fair and Appropriate Compensation.

With regard to the other four non-linear relationships, they are related to the effect of: hierarchy on IRA, in which we could observe a concave surface on the line of congruence $\left(\mathrm{a}_{1}=-2.47\right.$, n.s.; $\left.\mathrm{a}_{2}=2.41, p<0.05\right)$, with interpretation similar to that of Figure 1; egalitarianism on IRA, also with a concave surface on the line of congruence $\left(a_{1}=-2.89\right.$, n.s.; $a_{2}$ $=1.80, p<0.05)$ and similar interpretation; of conservatism on FAC with convex surface on the line of incongruence $\left(a_{3}\right.$ $=-8.59$, n.s.; $\left.\mathrm{a}_{4}=-4.25, p<0.05\right)$; and hierarchy on IS with convex surface on the line of incongruence $\left(a_{3}=-0.09\right.$, n.s.; $\left.\mathrm{a}_{4}=-1.90, p<0.05\right)$. Convex surfaces on the line of incongruence indicate that QWL related to the factor in question has its score reduced to the extent to which RV $>$ DV and the difference between them increases. That is, QWL related to FAC decreases sharply when real conservatism is greater than desired conservatism in the direction in which this difference increases. Similarly, QWL related to IS sharply decreases when real hierarchy is greater than desired hierarchy and this difference increases.

\section{Discussion}

This study's objective was to verify the effects of OV on QWL. The effects analysis was based on the person-organizational fit - POF -, regarding the workers' perceived and desired OV. The quadratic polynomial regression model was used with surface analysis charts, as the literature indicates that this is the most appropriate method to be applied to situations in which the investigation is based on two variables that compose a criterion (Edwards \& Parry, 1993; Shanock et al., 2010), which allows for a better explanation of the variance when compared to other methods and the verification of the existence of non-linear relationships between the independent and dependent variables. The variables considered were real and desired $\mathrm{OV}$, which together compose the coefficient of satisfaction related to the construct (Tamayo \& Borges, 2006; Tamayo et al., 2000).

The hypothesis that QWL is impacted by the workers' satisfaction with organizational values was confirmed. All 
quadratic regressions performed with each pair of factors that compose the independent variable $\mathrm{OV}$ and the dependent variable QWL explained the variance of the first on the second, with statistical significance. These findings can encourage organizations to reflect upon the values they declare and those that are in fact put into practice, in order to develop strategies intended to promote greater congruence from the perspective of workers, positively impacting QWL and consequently, productivity, as reported in the literature (Mejbel et al., 2013; Walton, 1973, 1980).

The use of quadratic regression with surface analysis charts revealed that some relationships between criterion and outcome variables are not linear. This finding is relevant for researchers addressing congruence in the field of organizational behavior, as it supports decision making with regard to what model to adopt in studies. The results are also consistent with the literature that defends that polynomial quadratic regression with surface analysis charts is an approach that permits examining the extent to which the combination of two predictor variables affects the result of another variable (Edwards \& Parry, 2003; Shanock et al., 2010), particularly when the investigation is based on the congruence/discrepancy between two predictor variables, as is the case of this study (RV and DV).

Non-linear relationships were found in the composition of the effect of four OV factors (autonomy; conservatism; hierarchy; and egalitarianism) on three of the QWL factors (integration, respect and autonomy; fair and appropriate compensation; and incentive and support). The non-linear relationships indicate there is maximum expectation of improvement for the QWL factors, which remain stable after achieving this level (though it may decrease) in case congruence/discrepancy of OV continue changing. The chart in Figure 2 provides a perspective on this type of situation. There is a point of inflection on the surface and one can see that, when congruence obtains higher scores of OV, QWL increases. When, however, congruence obtains lower scores, QWL decreases.

This is important for organizations because it leads to more precise definitions of actions and interventions intended to actually promote QWL. This is so because, in cases similar to that exemplified in figure 2, the analysis shows that improved results are achieved when expectation and reality are congruently higher. Therefore, in the case of incongruence, attempting to decrease the expectations of workers to achieve congruence is not recommended. As the results show, this type of intervention could lead to satisfaction with $\mathrm{OV}$ and to a worse perception of QWL. In the same sense, the findings indicate that, if real conservatism is greater than desired conservatism, QWL related to FAC decreases when the difference between them increases. The same is true for the effect of the hierarchy value on QWL related to IS. This information indicates that organizations should carefully assess the type of intervention to be performed if they desire to promote QWL by implementing interventions to affect $\mathrm{OV}$.

In this study, the congruence of OV that explain most of the variance in QWL was egalitarianism. The effects of this factor on QWL related to IRA and IS were non-linear in the surface analysis of the line of congruence and linear in the surface analysis of the line of maximum incongruence.
This type of information shows that there are scoring ranges in which QWL can be greater when there is incongruence than when there is congruence, which somewhat contradicts the initial hypothesis, showing that it was not fully confirmed for all the relationships. A potential explanation for this fact is that a larger effect of incongruence occurs when the workers' perceived egalitarianism (RV) is placed above their expectations with regard to DV and that the hypothesis was not originally proposed considering different directions of incongruence (DV $>\mathrm{RV}$ and $\mathrm{DV}<\mathrm{RV})$.

In general, this study's findings suggest that satisfaction with OV affects QWL, but such an effect may have a limited impact that, when achieved, indicates that new interventions intended to change the satisfaction of workers with OV would not increase QWL. The study also shows that congruence by itself will not always determine a positive impact on QWL because positive situations for QWL can occur when the company exceeds the expectations of workers with regard to specific OV.

As any exploratory research, this study presents limitations, including the fact that data were collected via internet, which does not allow for the clarification of potential doubts in real time; the small sample size and its general characteristics, considering the large number of professionals with a college degree, which may have resulted in unbalanced data with regard to a more representative population of the real organizational environment; and the exclusive use of self-report scales, one of which (OVI) may lead to a social desirability bias, as the items of real and desired values are presented side-by-side, perhaps conveying the idea that what one desires should be different (if not greater or better) from what one actually has.

Despite these limitations, this study contributes to a broader understanding of the impact promoted by the POF of organizational values on workers' QWL. Therefore, the understanding of non-linear relationships among the constructs also contributes to the generation of insights that may lead to organizational strategies, whose values may improve QWL and, consequently, productivity. The sample was composed of professionals working in companies of different sizes from various sectors and occupying different positions at different hierarchical levels. Even though this was not the focus of this analysis, it is an issue that instigates new research questions to confirm these findings in intra-sectorial or intra-company situations.

Another contribution refers to the statistical method adopted; the quadratic regression with surface analysis chart is seldom used in psychological studies in Brazil. In this sense, new studies could address relationships and impacts on the scope of organizational behavior measures. These studies could also contribute to the dissemination and greater appropriation of the framework of analysis this approach permits.

\section{References}

Adeyemo, D. A., Terry, D. L., \& Lambert, N. J. (2015). Organizational climate, leadership style and emotional intelli- 
gence as predictors of quality of work life among bank workers in Ibadan, Nigeria. European Scientific Journal, 11(4), 110-130. Retrieved from http://eujournal.org/index. php/esj/article/view/5145/5034

Almalki, M. J., FitzGerald, G., \& Clark, M. (2012). The relationship between quality of work life and turnover intention of primary health care nurses in Saudi Arabia. BMC Health Services Research, 12, 314. doi:10.1186/14726963-12-314

Argüelles Ma, L. A., Quijano García, R. A., Fajardo, M. J., Magaña Medina, D. E., \& Sahuí Maldonado, J. A. (2014). Propuesta de modelo predictivo de la calidad de vida laboral en el sector turistico Campechano, Mexico [Proposal predictive model of quality of working life in tourism Campechano, Mexico]. Revista Internacional Administración \& Finanzas, 7(5), 61-76.

Barzegar, M., Afzal, E., Tabibi, S. J., Delgoshaei, B., \& Koochakyazdi, S. (2012). Relationship between leadership behavior, quality of work life and human resources productivity: Data from Iran. International Journal of Hospital Research, 1(1), 1-14.

Campos, M. I., \& Rueda, F. J. M. (2016). Assédio moral: Evidências de validade de escala e relações com qualidade de vida no trabalho. [Workplace bullying: Scale validity evidence and relationship to quality of work life]. Avaliação Psicológica, 15(1), 21-30. doi:10.15689/ap.2016.1501.03

Contreras, F., Espinosa, J. C., Hernández, F., \& Acosta, N. (2013). Calidad de vida laboral y liderazgo en trabajadores asistenciales y administrativos en un centro oncológico de Bogotá (Colombia) [Work quality of life and leadership in administrative staff and health care personnel of an oncological center in Bogotá (Colombia)]. Psicología Desde el Caribe, 30(3), 569-590. Recuperado de http://www.scielo. org.co/pdf/psdc/v30n3/v30n3a07.pdf

Edwards, J. R., \& Parry, M. E. (1993). On the use of polynomial regression equations as an alternative to difference scores in organizational research. Academy of Management Journal, 36(6), 1577-1613. doi:10.2307/256822

Erdem, M. (2014). The level of quality of work life to predict work alienation. Educational Sciences: Theory \& Practice, 14(2), 534-544. doi:10.12738/estp.2014.2.2126

Maroco, J., \& Garcia-Marques, T. (2006). Qual a fiabilidade do alfa de Cronbach? Questões antigas e soluções modernas? [How reliable is Cronbach's alpha? Old issues and modern solutions?] Laboratório de Psicologia, 4(1), 65-90.

Mejbel, A. A., Almsafir, M. K., Siron, R., \& Alnaser, A. S. M. (2013). The Drivers of Quality of Working Life (QWL): A critical review. Australian Journal of Basic and Applied Sciences, 7(10), 398-405.

Mendonça, M. A., Hora, H. R. M., Costa, H. G., \& Monteiro, G. T. R. (2014). Qualidade de vida no trabalho no setor petrolífero: Uma comparação entre os colaboradores onshore e offshore. [Quality of working life in the oil sector: a comparison between onshore and offshore workers].
Revista Brasileira de Qualidade de Vida, 6(2), 115-129. doi:10.3895/S2175-08582014000200006

Nespeca, M., \& Cyrillo, D. C. (2011). Qualidade de vida no trabalho de funcionários públicos: Papel da nutrição e da qualidade de vida [Life quality in civil servants' labor: the roles of nutrition and life quality]. Acta Scientiarum.

Health Science, 33(2), 187-195. doi:10.4025/actascihealthsci.v33i2.7885

Nowrouzi, B., Lightfoot, N., Carter, L., Larivière, M., Rukholm, E., Schinke, R., \& Belanger-Gardner, D. (2015). The relationship between quality of work life and location of cross-training among obstetric nurses in urban northeastern Ontario, Canada: A population-based cross sectional study. International Journal of Occupational Medicine and Environmental Health, 28(3), 571-586. doi:10.13075/ijomeh.1896.00443

Oliveira, A. F., \& Souza, M. A. (2014). Confiança do empregado na organização: O impacto dos valores pessoais e organizacionais. [Employee confidence in the organization: impact of personal and organizational values]. Revistas Psicologia Organizações e Trabalho, 14(2), 204-217.

Ouppara, N. S., \& Sy, M. V. U. (2012). Quality of work life practices in a multinational company in Sydney, Australia. Procedia - Social and Behavioral Sciences, 40, 116-121. doi:10.1016/j.sbspro.2012.03.169

Pedroso, B., \& Pilatti, L. A. (2010). Revisão literária dos modelos clássicos de avaliação da qualidade de vida no trabalho: Um debate necessário [Literary review of the classic models of quality of life at work evaluation: A necessary debate]. In R. Vilarta, G. L. Gutierrez, M. I. Monteiro (Orgs.), Qualidade de vida: Evolução dos conceitos e práticas no século $X X I$ [Quality of life: Evolution of concepts and practices in the 21 st century] (pp. 197-206). Campinas, SP: Ipes.

Rueda, F. J. M. (2013). Escala de Avaliação de Qualidade de Vida no Trabalho (Escala-QWL). [Quality of Life at Work Rating Scale (QWL-Scale)] São Paulo, SP: Casa do Psicólogo.

Rueda, F. J. M., Ottati, F., Pinto, L. P., Lima, T. H., \& Bueno, J. M. P. (2013). Construção e validação de uma escala de avaliação da qualidade de vida no trabalho [Development and validation of a quality of life at work scale]. Avaliação Psicológica, 12(1), 43-50. Recuperado de http://pepsic.bvsalud.org/scielo.php?script=sci_arttext\&pid=S1677-04712013000100007 \&lng=pt\&nrm=iso

Rueda, F. J. M., Serenini, A. L. P., \& Meireles, E. (2014). Relação entre qualidade de vida no trabalho e confiança do empregado na organização. [Relationship between quality of work life and trust employee in the organization]. Revista Psicologia Organizações e Trabalho. 14(3), 303-314. Recuperado de http://pepsic.bvsalud.org/scielo.php?script=sci_arttext\&pid=S1984-66572014000300006 \&lng=pt\&nrm=iso

Saraç, M., Efil, I., \& Eryilmaz, M. (2014). A study of the relationship between person-organization fit and employee creativity. Management Research Review, 37(5), 479-501. doi:10.1108/MRR-01-2013-0025 
Shanock, L. R., Baran, B. E., Gentry, W. A., Pattison, S. C., \& Heggestad, E. D. (2010). Polynomial regression with response surface analysis: A powerful approach for examining moderation and overcoming limitations of difference scores. Journal of Business and Psychology, 25(4), 543-554. doi:10.1007/s10869-010-9183-4

Silva, C. A., \& Ferreira, M. C. (2013). Dimensões e indicadores da qualidade de vida e do bem-estar no trabalho [Dimensions and indicators of quality of life and well-being at work]. Psicologia: Teoria e Pesquisa, 29(3), 331-339. doi:10.1590/s0102-37722013000300011

Sousa, J. M., \& Porto, J. B. (2015). Happiness at work: Organizational values and person-organization fit impact. Paidéia (Ribeirão Preto), 25(61), 211-220. doi:10.1590/198243272561201509

Šverko, B., \& Galić, Z. (2014). The perceived quality of working life in Croatia and the European Union. Društvena Istraživanja, 23(4), 557-575. doi:10.5559/di.23.4.01

Tamayo, A., \& Borges, L. O. (2006). Valores do trabalho e das organizações [Work and organizational values]. In M. Ros $\&$ V. V. Gouveia (Orgs.), Psicologia social dos valores humanos: Desenvolvimentos teóricos, metodológicos e aplicados [Social psychology of human values: Theoretical, methodological and applied developments]. (O. Cafalcchio, Trad., pp. 397-431). São Paulo, SP: Editora Senac.

Tamayo, A., Mendes, A. M., \& Paz, M. G. T. (2000). Inventário de valores organizacionais. [Organizational values inventory]. Estudos de Psicologia (Natal), 5(2), 289-315. doi:10.1590/S1413-294X2000000200002

Walton. R. E. (1973). Quality of working life: What is this? Sloan Management Review, 15(1), 11-21.

Walton, R. E. (1980). Quality of work life activities: A research agenda. Professional Psychology, 11(3), 484-493. doi:10.1037/0735-7028.11.3.484

Maria Isabel de Campos is a Ph.D. candidate and master in the Stricto Sensu Graduate Program in Psychology at Universidade São Francisco, Campinas, São Paulo, Brazil.

Fabián Javier Marin Rueda is a Professor in the Stricto Sensu Graduate Program in Psychology at Universidade São Francisco, Campinas, São Paulo, Brazil.

Received: Mar. 18, 2016

1st Revision: Aug. 3, 2016

Approved: Oct. 11, 2016

How to cite this article:

Campos, M. I., \& Rueda, F. J. M. (2017). Effects of organizational values over quality of work life. Paidéia (Ribeirão Preto), 27(67), 65-75. doi: 10.1590/198243272767201708 